\title{
THE MECHANISMS OF INCREASING SOCIAL AND POLITICAL ACTIVITY OF CITIZENS IN THE PROCESS OF MODERNIZATION OF SOCIETY
}

\author{
Akhmadjonov Olimjon \\ Andijan State University \\ The department of Democratic Society
}

Article DOI: https://doi.org/10.36713/epra3982

\section{ABSTRACT \\ "Society is the initiator of reforms"}

"Sh. M. Mirziyoyev"

From year to year our life has developed, achieved great results and achievements in various spheres of social and political development, and has been strived for the highest level in the world community. At the same time, democratization and renewal of society, modernization and reforming of the country require particular attention as a priority in expanding the participation of the population in the socio-political life.

Decree of the President of the Republic of Uzbekistan No. 4947 PD “On the Strategy of actions for further development of the Republic of Uzbekistan" of 7 February 2017, which has played an important role in the new stage of national development of Uzbekistan, democratization and liberalization of social and political life, protection of human rights and freedoms, state and the main directions of effective communication between the population, has been developed.

\section{DISCUSSION}

The fate of the ongoing reforms, the effectiveness and prospects for democratization are largely dependent on the active participation of citizens and the participation of the population in the sociopolitical processes, since one of the factors determining the socio-political potential of the state is determined by the commitment, intelligence and selflessness of the citizens of the country. As the main goal of building a democratic state and a strong civil society in our country, the fate of democracy, in many respects, depends on the participation of citizens in the sociopolitical processes.

Therefore, in order to deepen democratic reforms, it is necessary to become a genuine participant of democratic processes and active advocate for democratic values. This requires constant development of the process.

The state of citizens' participation in the sociopolitical processes largely depends on the spiritual environment in the society, the system of public administration, and the human factor. It is natural that the person's involvement in social and political processes varies widely. The existence of democratic values in the human mind, its understanding of its constitutional duty and its exercise of personal rights, the degree of its moral and enlightenment knowledge are, in general, defined as an opportunity to thoroughly analyze what is happening in our lives.

The participation of the population in the democratic life of the democratic states is reflected in the participation of citizens in the formation of the government, participation in the decision-making and control over the implementation of issues which are significantly important, in support of the ongoing reforms.

It is also important to note that the participation of citizens in socio-political processes also depends on the degree of participation of democratic institutions, parties, non-governmental and public organizations.

Indeed, as noted by the head of state, the role of non-governmental, non-profit and community organizations is very important in strengthening democratic reforms in the minds of people, enhancing their political and civic activity, and expanding and deepening democratic reforms in the country.

It is the civil institutions, non-profit organizations that have the ability to freely monitor independent thinking, social and political processes, to have their own civic position, to take an active part in the creative endeavors undertaken in our country, to be able to develop the necessary forms of human activity. It is an important tool for developing the skills to pay particular attention to the formation of the human mind. 
As the first President of the Republic of Uzbekistan IA Karimov said, "The political activity of the population has to be repeatedly stated that it is still inadequate and still inadequate. We have to admit that we cannot completely get rid of old patterns. All of the important decisions are made from above, and it is difficult for us to lose the defects of the administrative, commanding, totalitarian system that have only made us subordinate executives and sometimes victims of unintended decisions. The political culture needs to be enhanced. People need to know how decisions are made, how their performance is monitored, and actively participate in the preparation and implementation of these decisions. In other words, it is necessary to be aware of the way in which the society is elected at the center and at the local level. Everyone should know their place in society and feel themselves an integral part of their society.

The idea of from national revival to national progress put forward is considered to be a practical program which is thought to deal with aforementioned defects.

The essence of the work on further development of Uzbekistan's integration into the world community, modernization of social and political life of the country, including democratization of state power and governance, judicial system, development of electoral legislation, further deepening of civil society institutions, citizen activism plays a very important role in the deeper understanding. It is noteworthy that, given the objectives set out in the Development Strategy of Uzbekistan; modernization of the society and increasing the participation of citizens in social and political life should be reflected in the following mechanisms:

- Further formation of the legal culture of citizens in the process of modernization and renewal of society;

- Strengthening effective public control over the activities of state and government structures;

- Ensuring full utilization of constitutional rights to ensure active participation of citizens in social and political life;

- Use of effective methods for further strengthening of civil society institutions in civil selfgovernance;

- Further strengthening and development of democratic skills in the minds of citizens;

- Strengthen practical work aimed at further strengthening the political participation of the population in the electoral process;

- Formation of a sense of belonging to the socio-political, spiritual and educational attitudes of the youth;

- To further increase social and political activity of women in society;

- To create in citizens' minds the feeling of love for the country, prosperity of the nation, commitment to duty.
The President of the Republic of Uzbekistan Shavkat Mirziyoev said in his address to the Parliament of the Republic of Uzbekistan on January 24, 2020 that we are making great progress in the development of our country, based on the intelligence, power and potential of our people. Most importantly, the results of our reforms should be felt by every person, every family living in our country today. To do this, leaders at all levels must work to ensure that every citizen has conveniences needed instead of chasing after interests, per cents, numbers, or papers. Then the idea that all our multinational people will be pleased with us is an indication of the main goal of our renewed development strategy of Uzbekistan.

\section{REFERENCES}

1. Decree of the President of the Republic of Uzbekistan Sh.M. Mirziyoyev No. 4947 of 7 February, 2017 "On the strategy of further development of the Republic of Uzbekistan"

2. Decree by the President of the Republic of Uzbekistan No. PD-5430 on measures to complete enhancement of the role of civil society institutions in the democratic renewal of the country T.: May 4, 2018.

3. Address by the President of the Republic of Uzbekistan to the Parliament - Oliy Majlis of the Republic of Uzbekistan January 24, 2020

4. Speech of the President of the Republic of Uzbekistan Sh.Mirziyoev at the solemn ceremony, devoted to the 27th anniversary of the Constitution of the Republic of Uzbekistan. T .: December 7, 2019.

5. Karimov I.A. Further deepening of democratic reforms and formation of civil society is the main criterion of development of our country. T. Volume 19 